\title{
Bureau of Justice Statistics
}

\section{Bulletin}

November 2006, NCJ 215092

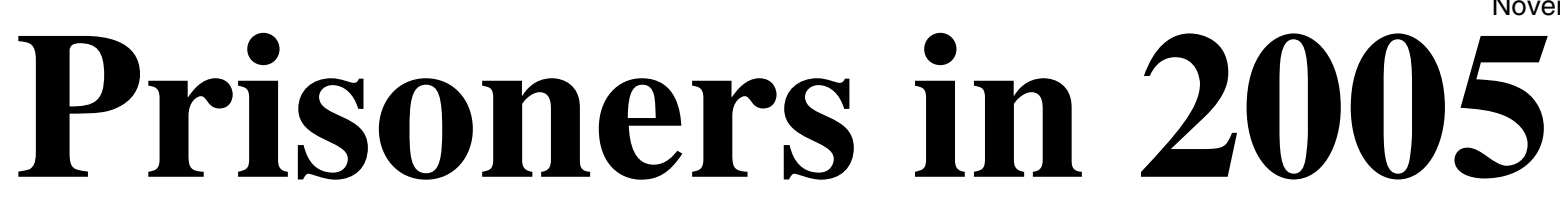

\author{
By Paige M. Harrison and \\ Allen J. Beck, Ph.D. \\ BJS Statisticians
}

The total number of prisoners under the jurisdiction of Federal or State adult correctional authorities was $1,525,924$ at yearend 2005. During the year the States added 21,534 prisoners and the Federal prison system added 7,290 prisoners. Overall, the Nation's prison population grew $1.9 \%$, which was less than the average annual growth of $3.1 \%$ since yearend 1995 .

The rate of incarceration in prison at yearend 2005 was 491 sentenced inmates per 100,000 U.S. residents, up from 411 in 1995. About 1 in every 108 men and 1 in every 1,538 women were sentenced prisoners under the jurisdiction of State or Federal authorities.

Overall, the United States incarcerated 2,320,359 persons at yearend 2005 .

This total represents persons held in -

- Federal and State prisons $(1,446,269$, which excludes State and Federal prisoners in local jails)

— territorial prisons $(15,735)$

— local jails $(747,529)$

— facilities operated by or exclusively for the Bureau of Immigration and Customs Enforcement $(10,104)$

— military facilities $(2,322)$

— jails in Indian country (1,745 as of midyear 2004)

— juvenile facilities $(96,655$ as of 2003).

\section{Highlights}

\begin{tabular}{|c|c|c|c|c|c|}
\hline $\begin{array}{l}\text { Prison } \\
\text { population }\end{array}$ & $\begin{array}{l}\text { Number } \\
\text { of inmates }\end{array}$ & $\begin{array}{l}\text { Incarceration } \\
\text { rate, 12/31/05 }\end{array}$ & $\begin{array}{l}\text { Inmates per } \\
100,000 \text { residents }\end{array}$ & $\begin{array}{l}\text { Growth, } 12 / 31 / 04 \\
\text { to } 12 / 31 / 05\end{array}$ & $\begin{array}{l}\text { Percent } \\
\text { change }\end{array}$ \\
\hline \multicolumn{6}{|l|}{5 highest: } \\
\hline Federal & 187,618 & Louisiana & 797 & South Dakota & $11.9 \%$ \\
\hline California & 170,676 & Texas & 691 & Montana & 10.9 \\
\hline Texas & 169,003 & Mississippi & 660 & Kentucky & 10.4 \\
\hline Florida & 89,768 & Oklahoma & 652 & Nebraska & 7.9 \\
\hline New York & 62,743 & Alabama & 591 & Alabama & 7.7 \\
\hline \multicolumn{6}{|l|}{5 lowest: } \\
\hline North Dakota & 1,385 & Maine & 144 & Georgia & $-4.6 \%$ \\
\hline Maine & 2,023 & Minnesota & 180 & Maryland & -2.4 \\
\hline Wyoming & 2,047 & Rhode Island & 189 & Louisiana & -2.3 \\
\hline Vermont & 2,078 & New Hampshire & 192 & Mississippi & -2.2 \\
\hline New Hampshire & 2,530 & North Dakota & 208 & Arkansas & -2.1 \\
\hline
\end{tabular}

\section{During 2005 -}

- Fourteen States had prison population increases of at least $5 \%$, led by South Dakota (up 11.9\%), Montana (up 10.9\%), and Kentucky (up $10.4 \%)$.

- Eleven States experienced prison population decreases, led by Georgia (down 4.6\%), Maryland (down 2.4\%), Louisiana (down 2.3\%), and Mississippi (down 2.2\%).

- State inmates held in private prison facilities increased $8.8 \%$, reaching 80,401 at yearend 2005 .

- Federal inmates held in private facilities increased $9.2 \%$ to 27,046 .

- State and Federal inmates held in local jails decreased $1.8 \%$ to 73,097 .
On December 31, 2005 -

- 1 in every 136 U.S. residents was in prison or jail.

- Local jails housed 73,097 State and Federal inmates $(4.8 \%$ of all prisoners).

- State prisons were operating between $1 \%$ below and $14 \%$ above capacity; Federal prisons were operating at $34 \%$ above capacity.

- Women made up $7.0 \%$ of all inmates, up from 6.1\% in 1995.

- About $8.1 \%$ of black males age 25 to 29 were in State or Federal prison, compared to $2.6 \%$ of Hispanic males and $1.1 \%$ of white males in the same age group. 
Nearly $\mathbf{2 . 2}$ million persons in prison or jail at yearend 2005

On December 31, 2005, a total of $1,446,269$ inmates were in the custody of State and Federal prison authorities, and 747,529 were in the custody of local jail authorities (table 1). (Custody is defined on page 11.) The total incarcerated population increased by 58,463 , or $2.7 \%$ from yearend 2004 . This is less than the average annual increase of $3.3 \%$ since 1995 .

Including inmates in public and privately operated facilities, the number of inmates in State prisons increased
$1.3 \%$ during 2005; the number in Federal prisons, $5.1 \%$; and in local jails, $4.7 \%$.

The rate of incarceration in prison and jail was 737 inmates per 100,000 U.S. residents in 2005, up from 601 in 1995. At yearend 2005, 1 in every 136 U.S. residents was incarcerated in a State or Federal prison or a local jail.

\section{U.S. prison population rose $1.9 \%$ during 2005}

In 2005 the percentage increase in inmates under State or Federal jurisdiction $(1.9 \%)$ was the same as

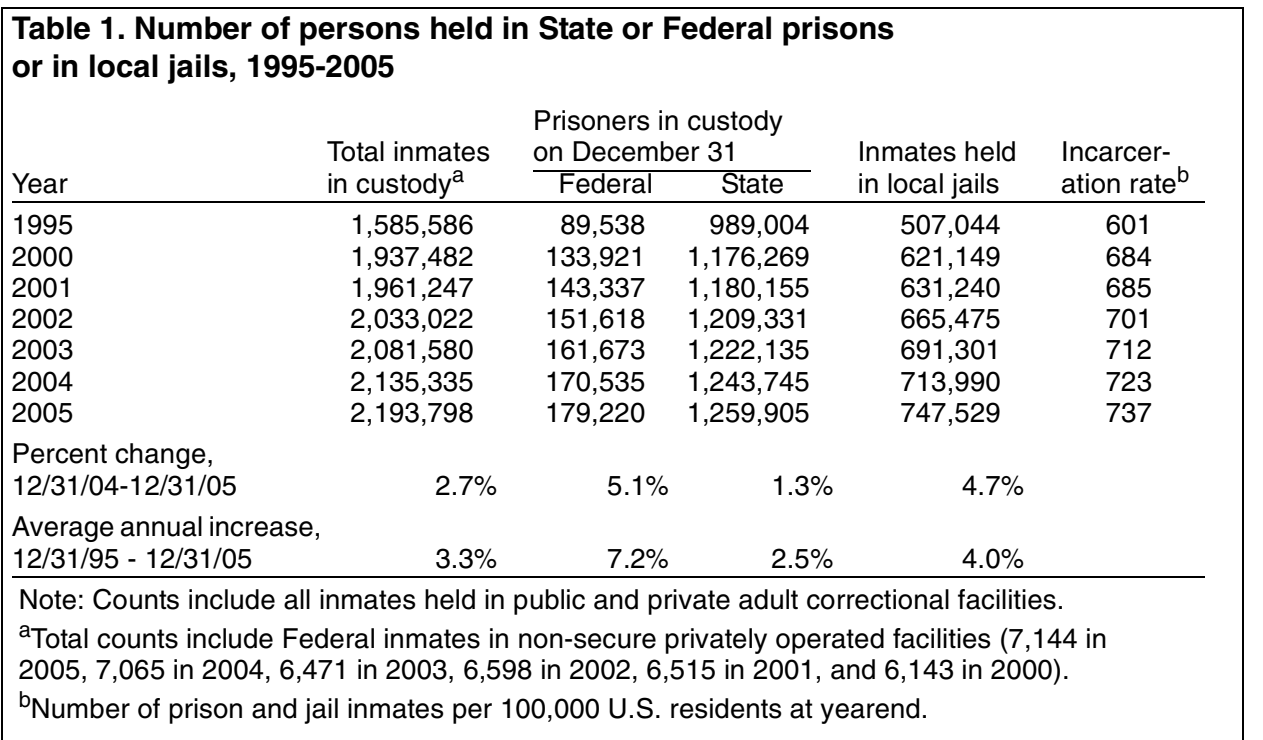

recorded in 2004 (table 2). (Jurisdiction is defined on page 11.) The population under the jurisdiction of State and Federal authorities increased by 28,824 inmates during 2005, slightly larger than the increase in 2004 (up 28,499). Since December 31, 1995, the U.S. prison population has grown an average of 44,527 inmates per year (3.1\%).

The Federal prison population totaled 187,618 at yearend 2005 , up from 180,328 at yearend 2004 . About $12 \%$ of all prisoners were serving time in the Federal system.

Table 2. Change in State and Federal prison populations, 1995-2005

\begin{tabular}{|c|c|c|c|}
\hline Year & Custody & Jurisdiction & $\begin{array}{l}\text { Percent } \\
\text { change }\end{array}$ \\
\hline 1995 & 88,395 & 71,172 & $6.7 \%$ \\
\hline 1996 & 49,222 & 57,494 & 5.1 \\
\hline 1997 & 48,800 & 58,785 & 5.0 \\
\hline 1998 & 47,905 & 58,420 & 4.7 \\
\hline 1999 & 36,957 & 43,796 & 3.4 \\
\hline 2000 & 25,182 & 18,191 & 1.3 \\
\hline 2001 & 14,647 & 15,521 & 1.1 \\
\hline 2002 & 37,457 & 36,112 & 2.6 \\
\hline 2003 & 29,330 & 28,457 & 2.0 \\
\hline 2004 & 30,472 & 28,499 & 1.9 \\
\hline 2005 & 24,845 & 28,824 & 1.9 \\
\hline $\begin{array}{l}\text { Average annual } \\
\text { increase, 1995- } \\
2005\end{array}$ & 43,321 & 44,527 & $3.1 \%$ \\
\hline \multicolumn{4}{|c|}{$\begin{array}{l}\text { Note: Counts based on comparable methods } \\
\text { were used to calculate the annual increase } \\
\text { and percent change. } \\
{ }^{*} \text { Percent change in total number of prisoners } \\
\text { under State and Federal jurisdiction. }\end{array}$} \\
\hline
\end{tabular}

\section{5,735 inmates held in U.S. Territories at yearend 2005}

The U.S. Territories and Commonwealths - American Samoa, Guam, Northern Mariana Islands, Puerto Rico, and Virgin Islands - reported 15,735 inmates in the custody of their prison systems at yearend 2005, a decrease of 22 persons from 2004. Puerto Rico held the largest number of sentenced prisoners, 11,469 at yearend 2005 .

Prisoners with a sentence of more than 1 year totaled 12,399 (more than three-quarters of the total territorial prison population).
Relative to the resident population in the Territories, the rate of incarceration was 287 prisoners per 100,000 residents. Of the 5 Territories, the U.S.

Prisoners in custody of correctional authorities in the U.S. Territories and Commonwealths, yearend 2004 and 2005

\begin{tabular}{|c|c|c|c|c|c|c|c|}
\hline \multirow[b]{2}{*}{ Jurisdiction } & \multicolumn{3}{|c|}{ Total } & \multicolumn{4}{|c|}{ Sentenced to more than 1 year } \\
\hline & 2005 & 2004 & $\begin{array}{l}\text { Percent } \\
\text { change, } \\
2004-05\end{array}$ & 2005 & 2004 & $\begin{array}{l}\text { Percent } \\
\text { change, } \\
2004-05\end{array}$ & $\begin{array}{l}\text { Incarcera- } \\
\text { tion rate, } \\
2005^{\star}\end{array}$ \\
\hline Total & 15,735 & 15,757 & $-0.1 \%$ & 12,399 & 12,185 & $1.8 \%$ & 287 \\
\hline American Samoa & 222 & 258 & -14.0 & 174 & 165 & 5.5 & 301 \\
\hline Guam & 505 & 393 & 28.5 & 238 & 122 & 95.1 & 141 \\
\hline $\begin{array}{l}\text { Commonwealth of } \mathrm{t} \\
\text { Northern Mariana } \\
\text { Islands }\end{array}$ & 149 & 150 & -0.7 & 83 & 98 & -15.3 & 103 \\
\hline $\begin{array}{l}\text { Commonwealth of } \\
\text { Puerto Rico }\end{array}$ & 14,263 & 14,380 & -0.8 & 11,469 & 11,374 & 0.8 & 293 \\
\hline U.S. Virgin Islands & 596 & 576 & 3.5 & 435 & 426 & 2.1 & 400 \\
\hline
\end{tabular}

${ }^{*}$ The number of prisoners with a sentence of more than 1 year per 100,000 persons in the resident population. Midyear population estimates were provided by the U.S. Census Bureau, International Data Base. 
14 States reported increases of at least $5 \%$ during 2005; 11 States had decreases

Between January 1 and December 31, 2005 , South Dakota experienced the largest increase in prison population (up $11.9 \%$ ), followed by Montana (up $10.9 \%$ ), Kentucky (up 10.4\%), and Nebraska (up 7.9\%) (table 3). Eleven States experienced a decline. Georgia had the largest decline (down 4.6\%), followed by Maryland (down 2.4\%), Louisiana (down 2.3\%), and Mississippi (down 2.2\%).

In absolute numbers four jurisdictions grew by at least 2,000 inmates during 2005, including the Federal system (up 7,290 ), Florida (up 4,235), California (up 4,120), and Alabama (up 2,001). Georgia and New York had the largest drop in inmates (down 2,355 and 1,008 , respectively).

Overall, the number of inmates under jurisdiction in the West grew $3.2 \%$, followed by those in the Midwest $(1.6 \%)$, the Northeast $(1.1 \%)$, and the South (1.0\%).

\section{Prison incarceration rate reached 491 per 100,000 residents in 2005, up from 411 in 1995}

Eleven States exceeded the national prison incarceration rate of 491 per 100,000 residents, led by Louisiana (797), Texas (691), Mississippi (660), and Oklahoma (652) (table 4). Seven States, led by Maine (144), Minnesota (180), and Rhode Island (189), had rates that were less than half the national rate.

Since 1995 the sentenced inmate population in State prisons has increased an average $3.0 \%$ per year. During this period, 12 States had an average annual growth of at least $5 \%$, led by North Dakota (up 9.3\%), West Virginia (up 7.9\%), and Oregon (up 7.5\%). Between 1995 and 2005 the Federal system grew an average of $7.1 \%$ per year. In absolute numbers this is an average annual increase of 8,251 inmates.
Table 3. Prisoners under the jurisdiction of State or Federal correctional authorities, by region and jurisdiction, 2004 and 2005

\begin{tabular}{|c|c|c|c|c|c|}
\hline \multirow[b]{2}{*}{$\begin{array}{l}\text { Region and } \\
\text { jurisdiction }\end{array}$} & \multirow[b]{2}{*}{$12 / 31 / 2005$} & \multirow[b]{2}{*}{ 06/30/2005 } & \multirow[b]{2}{*}{$12 / 31 / 2004$} & \multicolumn{2}{|c|}{ Percent change from - } \\
\hline & & & & $\begin{array}{l}12 / 31 / 04 \text { to } \\
12 / 31 / 2005\end{array}$ & $\begin{array}{l}6 / 30 / 05 \text { to } \\
12 / 31 / 2005\end{array}$ \\
\hline U.S. Total & $1,525,924$ & $1,513,213$ & $1,497,100$ & $1.9 \%$ & $0.8 \%$ \\
\hline $\begin{array}{l}\text { Federal } \\
\text { State }\end{array}$ & $\begin{array}{r}187,618 \\
1,338,306\end{array}$ & $\begin{array}{r}184,484 \\
1,328,729\end{array}$ & $\begin{array}{r}180,328 \\
1,316,772\end{array}$ & $\begin{array}{l}4.0 \% \\
1.6\end{array}$ & $\begin{array}{l}1.7 \% \\
0.7\end{array}$ \\
\hline $\begin{array}{l}\text { Northeast } \\
\text { Connecticut }^{\mathrm{a}} \\
\text { Maine } \\
\text { Massachusetts } \\
\text { New Hampshire } \\
\text { New Jersey } \\
\text { New York } \\
\text { Pennsylvania } \\
\text { Rhode Island } \\
\text { Vermont }^{\mathrm{a}}\end{array}$ & $\begin{array}{r}172,910 \\
19,442 \\
2,023 \\
10,701 \\
2,530 \\
27,359 \\
62,743 \\
42,380 \\
3,654 \\
2,078\end{array}$ & $\begin{array}{r}173,125 \\
19,744 \\
2,084 \\
10,495 \\
2,561 \\
28,124 \\
62,963 \\
41,540 \\
3,639 \\
1,975\end{array}$ & $\begin{array}{r}170,982 \\
19,497 \\
2,024 \\
10,144 \\
2,448 \\
26,757 \\
63,751 \\
40,963 \\
3,430 \\
1,968\end{array}$ & $\begin{array}{l}1.1 \% \\
-0.3 \\
0.0 \\
5.5 \\
3.3 \\
2.2 \\
-1.6 \\
3.5 \\
6.5 \\
5.6\end{array}$ & $\begin{array}{l}-0.1 \% \\
-1.5 \\
-2.9 \\
2.0 \\
-1.2 \\
-2.7 \\
-0.3 \\
2.0 \\
0.4 \\
5.2\end{array}$ \\
\hline $\begin{array}{l}\text { Midwest } \\
\text { Illinois } \\
\text { Indiana } \\
\text { lowa } \\
\text { Kansas } \\
\text { Michigan } \\
\text { Minnesota } \\
\text { Missouri } \\
\text { Nebraska } \\
\text { North Dakota } \\
\text { Ohio } \\
\text { South Dakota } \\
\text { Wisconsin }\end{array}$ & $\begin{array}{r}254,706 \\
44,919 \\
24,455 \\
8,737 \\
9,068 \\
49,546 \\
9,281 \\
30,823 \\
4,455 \\
1,385 \\
45,854 \\
3,463 \\
22,720\end{array}$ & $\begin{array}{r}252,406 \\
44,669 \\
24,244 \\
8,578 \\
9,042 \\
49,014 \\
9,187 \\
31,066 \\
4,284 \\
1,338 \\
44,976 \\
3,344 \\
22,664\end{array}$ & $\begin{array}{r}250,592 \\
44,054 \\
24,008 \\
8,525 \\
8,966 \\
48,883 \\
8,758 \\
31,081 \\
4,130 \\
1,327 \\
44,806 \\
3,095 \\
22,959\end{array}$ & $\begin{array}{l}1.6 \% \\
2.0 \\
1.9 \\
2.5 \\
1.1 \\
1.4 \\
6.0 \\
-0.8 \\
7.9 \\
4.4 \\
2.3 \\
11.9 \\
-1.0\end{array}$ & $\begin{array}{l}0.9 \% \\
0.6 \\
0.9 \\
1.9 \\
0.3 \\
1.1 \\
1.0 \\
-0.8 \\
4.0 \\
3.5 \\
2.0 \\
3.6 \\
0.2\end{array}$ \\
\hline $\begin{array}{l}\text { South } \\
\text { Alabama } \\
\text { Arkansas } \\
\text { Delaware } \\
\text { Florida } \\
\text { Georgia }^{\mathrm{b}} \\
\text { Kentucky } \\
\text { Louisiana } \\
\text { Maryland } \\
\text { Mississippi } \\
\text { North Carolina } \\
\text { Oklahoma } \\
\text { South Carolina } \\
\text { Tennessee } \\
\text { Texas } \\
\text { Virginia } \\
\text { West Virginia }\end{array}$ & $\begin{array}{r}606,236 \\
27,888 \\
13,511 \\
6,944 \\
89,768 \\
48,749 \\
19,662 \\
36,083 \\
22,737 \\
20,515 \\
36,365 \\
24,826 \\
23,160 \\
26,369 \\
169,003 \\
35,344 \\
5,312\end{array}$ & $\begin{array}{r}606,361 \\
27,740 \\
13,469 \\
7,180 \\
87,545 \\
47,682 \\
18,897 \\
37,254 \\
23,276 \\
20,856 \\
36,399 \\
23,702 \\
23,896 \\
26,208 \\
171,338 \\
35,667 \\
5,252\end{array}$ & $\begin{array}{r}600,269 \\
25,887 \\
13,807 \\
6,927 \\
85,533 \\
51,104 \\
17,814 \\
36,939 \\
23,285 \\
20,983 \\
35,434 \\
24,508 \\
23,428 \\
25,884 \\
168,105 \\
35,564 \\
5,067\end{array}$ & $\begin{array}{l}1.0 \% \\
7.7 \\
-2.1 \\
0.2 \\
5.0 \\
-4.6 \\
10.4 \\
-2.3 \\
-2.4 \\
-2.2 \\
2.6 \\
1.3 \\
-1.1 \\
1.9 \\
0.5 \\
-0.6 \\
4.8\end{array}$ & $\begin{array}{l}0.0 \% \\
0.5 \\
0.3 \\
-3.3 \\
2.5 \\
2.2 \\
4.0 \\
-3.1 \\
-2.3 \\
-1.6 \\
-0.1 \\
4.7 \\
-3.1 \\
0.6 \\
-1.4 \\
-0.9 \\
1.1\end{array}$ \\
\hline $\begin{array}{l}\text { West } \\
\text { Alaska }^{\mathrm{a}} \\
\text { Arizona }^{\mathrm{b}} \\
\text { California } \\
\text { Colorado } \\
\text { Hawaii } \\
\text { Idaho }^{\mathrm{a}} \\
\text { Montana } \\
\text { Nevada } \\
\text { New Mexico } \\
\text { Oregon } \\
\text { Utah } \\
\text { Washington } \\
\text { Wyoming }\end{array}$ & $\begin{array}{r}304,454 \\
4,812 \\
33,471 \\
170,676 \\
21,456 \\
6,146 \\
6,818 \\
3,509 \\
11,782 \\
6,571 \\
13,411 \\
6,373 \\
17,382 \\
2,047\end{array}$ & $\begin{array}{r}296,837 \\
4,630 \\
32,664 \\
166,532 \\
20,841 \\
6,071 \\
6,526 \\
3,369 \\
11,565 \\
6,595 \\
13,317 \\
6,013 \\
16,688 \\
2,026\end{array}$ & $\begin{array}{r}294,929 \\
4,554 \\
32,515 \\
166,556 \\
20,293 \\
5,960 \\
6,375 \\
3,164 \\
11,365 \\
6,379 \\
13,183 \\
5,991 \\
16,614 \\
1,980\end{array}$ & $\begin{array}{l}3.2 \% \\
5.7 \\
2.9 \\
2.5 \\
5.7 \\
3.1 \\
6.9 \\
10.9 \\
3.7 \\
3.0 \\
1.7 \\
6.4 \\
4.6 \\
3.4\end{array}$ & $\begin{array}{l}2.6 \% \\
3.9 \\
2.5 \\
2.5 \\
3.0 \\
1.2 \\
4.5 \\
4.2 \\
1.9 \\
-0.4 \\
0.7 \\
6.0 \\
4.2 \\
1.0\end{array}$ \\
\hline
\end{tabular}




\begin{tabular}{|c|c|c|c|c|c|c|}
\hline $\begin{array}{l}\text { Region and } \\
\text { jurisdiction }\end{array}$ & $12 / 31 / 2005$ & $12 / 31 / 2004$ & 12/31/1995 & $\begin{array}{l}\text { Percent } \\
\text { change, } \\
2004-05\end{array}$ & $\begin{array}{l}\text { Average } \\
\text { change, } \\
1995-05^{a}\end{array}$ & $\begin{array}{l}\text { Incarcera- } \\
\text { tion rate, } \\
2005\end{array}$ \\
\hline U.S. Total & $1,461,132$ & $1,433,728$ & $1,085,022$ & $1.9 \%$ & $3.0 \%$ & 491 \\
\hline $\begin{array}{l}\text { Federal } \\
\text { State }\end{array}$ & $\begin{array}{r}166,173 \\
1,294,959\end{array}$ & $\begin{array}{r}159,137 \\
1,274,591\end{array}$ & $\begin{array}{r}83,663 \\
1,001,359\end{array}$ & $\begin{array}{l}4.4 \\
1.6\end{array}$ & $\begin{array}{l}7.1 \\
2.6\end{array}$ & $\begin{array}{r}56 \\
435\end{array}$ \\
\hline $\begin{array}{l}\text { Northeast } \\
\text { Connecticut }^{\mathrm{b}} \\
\text { Maine } \\
\text { Massachusetts }^{\mathrm{c}} \\
\text { New Hampshire } \\
\text { New Jersey } \\
\text { New York } \\
\text { Pennsylvania } \\
\text { Rhode Island }^{\mathrm{b}} \\
\text { Vermont }^{\mathrm{b}}\end{array}$ & $\begin{array}{r}162,641 \\
13,121 \\
1,905 \\
9,081 \\
2,520 \\
27,359 \\
62,743 \\
42,345 \\
2,025 \\
1,542\end{array}$ & $\begin{array}{r}161,121 \\
13,240 \\
1,961 \\
8,688 \\
2,448 \\
26,757 \\
63,751 \\
40,931 \\
1,894 \\
1,451\end{array}$ & $\begin{array}{r}155,030 \\
10,419 \\
1,326 \\
10,427 \\
2,015 \\
27,066 \\
68,486 \\
32,410 \\
1,833 \\
1,048\end{array}$ & $\begin{array}{l}0.9 \% \\
-0.9 \\
-2.9 \\
4.5 \\
2.9 \\
2.2 \\
-1.6 \\
3.5 \\
6.9 \\
6.3\end{array}$ & $\begin{array}{l}0.5 \% \\
2.3 \\
3.7 \\
-1.4 \\
2.3 \\
0.1 \\
-0.9 \\
2.7 \\
1.0 \\
3.9\end{array}$ & $\begin{array}{l}298 \\
373 \\
144 \\
239 \\
192 \\
313 \\
326 \\
340 \\
189 \\
247\end{array}$ \\
\hline $\begin{array}{l}\text { Midwest } \\
\text { Illinois } \\
\text { Indiana }^{\mathrm{d}} \\
\text { lowa }^{\mathrm{d}} \\
\text { Kansas }^{\mathrm{d}} \\
\text { Michigan } \\
\text { Minnesota } \\
\text { Missouri } \\
\text { Nebraska } \\
\text { North Dakota } \\
\text { Ohio } \\
\text { South Dakota } \\
\text { Wisconsin }\end{array}$ & $\begin{array}{r}252,845 \\
44,919 \\
24,416 \\
8,737 \\
9,068 \\
49,546 \\
9,281 \\
30,803 \\
4,330 \\
1,327 \\
45,854 \\
3,454 \\
21,110\end{array}$ & $\begin{array}{r}249,545 \\
44,054 \\
23,939 \\
8,525 \\
8,966 \\
48,883 \\
8,758 \\
31,061 \\
4,038 \\
1,238 \\
44,806 \\
3,088 \\
22,189\end{array}$ & $\begin{array}{r}192,177 \\
37,658 \\
16,046 \\
5,906 \\
7,054 \\
41,112 \\
4,846 \\
19,134 \\
3,006 \\
544 \\
44,663 \\
1,871 \\
10,337\end{array}$ & $\begin{array}{l}1.3 \% \\
2.0 \\
2.0 \\
2.5 \\
1.1 \\
1.4 \\
6.0 \\
-0.8 \\
7.2 \\
7.2 \\
2.3 \\
11.9 \\
-4.9\end{array}$ & $\begin{array}{l}2.8 \% \\
1.8 \\
4.3 \\
4.0 \\
2.5 \\
1.9 \\
6.7 \\
4.9 \\
3.7 \\
9.3 \\
0.3 \\
6.3 \\
7.4\end{array}$ & $\begin{array}{l}383 \\
351 \\
388 \\
294 \\
330 \\
489 \\
180 \\
529 \\
245 \\
208 \\
400 \\
443 \\
380\end{array}$ \\
\hline $\begin{array}{l}\text { South } \\
\text { Alabama } \\
\text { Arkansas } \\
\text { Delaware } \\
\text { Florida } \\
\text { Georgia }^{\mathrm{e}} \\
\text { Kentucky } \\
\text { Louisiana } \\
\text { Maryland } \\
\text { Mississippi } \\
\text { North Carolina } \\
\text { Oklahoma } \\
\text { South Carolina } \\
\text { Tennessee } \\
\text { Texas } \\
\text { Virginia } \\
\text { West Virginia }\end{array}$ & $\begin{array}{r}583,132 \\
27,003 \\
13,383 \\
3,972 \\
89,766 \\
48,741 \\
19,215 \\
36,083 \\
22,143 \\
19,335 \\
31,522 \\
23,245 \\
22,464 \\
26,369 \\
159,255 \\
35,344 \\
5,292\end{array}$ & $\begin{array}{r}576,292 \\
25,257 \\
13,668 \\
4,087 \\
85,530 \\
51,089 \\
17,140 \\
36,939 \\
22,696 \\
19,469 \\
30,683 \\
22,913 \\
22,730 \\
25,884 \\
157,617 \\
35,564 \\
5,026\end{array}$ & $\begin{array}{r}446,491 \\
20,130 \\
8,520 \\
3,014 \\
63,866 \\
34,168 \\
12,060 \\
25,195 \\
20,450 \\
12,251 \\
27,914 \\
18,151 \\
19,015 \\
15,206 \\
127,766 \\
27,260 \\
2,483\end{array}$ & $\begin{array}{l}1.2 \% \\
6.9 \\
-2.1 \\
-2.8 \\
5.0 \\
-4.6 \\
12.1 \\
-2.3 \\
-2.4 \\
-0.7 \\
2.7 \\
1.4 \\
-1.2 \\
1.9 \\
1.0 \\
-0.6 \\
5.3\end{array}$ & $\begin{array}{l}2.7 \% \\
3.0 \\
4.6 \\
2.8 \\
3.5 \\
3.6 \\
4.8 \\
3.7 \\
0.8 \\
4.7 \\
1.2 \\
2.5 \\
1.7 \\
5.7 \\
2.2 \\
2.6 \\
7.9\end{array}$ & $\begin{array}{l}539 \\
591 \\
479 \\
467 \\
499 \\
533 \\
459 \\
797 \\
394 \\
660 \\
360 \\
652 \\
525 \\
440 \\
691 \\
464 \\
291\end{array}$ \\
\hline $\begin{array}{l}\text { West } \\
\text { Alaska }^{b} \\
\text { Arizona }^{\mathrm{e}} \\
\text { California } \\
\text { Colorado }^{\mathrm{d}} \\
\text { Hawaii }^{\mathrm{b}} \\
\text { Idaho }^{\text {Montana }} \\
\text { Nevada } \\
\text { New Mexico } \\
\text { Oregon } \\
\text { Utah } \\
\text { Washington } \\
\text { Wyoming } \\
\end{array}$ & $\begin{array}{r}296,341 \\
2,781 \\
31,411 \\
168,982 \\
21,456 \\
4,422 \\
6,818 \\
3,509 \\
11,644 \\
6,292 \\
13,390 \\
6,269 \\
17,320 \\
2,047 \\
\end{array}$ & $\begin{array}{r}287,633 \\
2,632 \\
31,106 \\
164,933 \\
20,293 \\
4,174 \\
6,375 \\
3,164 \\
11,280 \\
6,111 \\
13,167 \\
5,915 \\
16,503 \\
1,980 \\
\end{array}$ & $\begin{array}{r}207,661 \\
2,042 \\
20,291 \\
131,745 \\
11,063 \\
2,590 \\
3,328 \\
1,999 \\
7,713 \\
3,925 \\
6,515 \\
3,447 \\
11,608 \\
1,395 \\
\end{array}$ & $\begin{array}{l}3.0 \% \\
5.7 \\
1.0 \\
2.5 \\
5.7 \\
5.9 \\
6.9 \\
10.9 \\
3.2 \\
3.0 \\
1.7 \\
6.0 \\
5.0 \\
3.4 \\
\end{array}$ & $\begin{array}{l}3.6 \% \\
3.1 \\
4.5 \\
2.5 \\
6.8 \\
5.5 \\
7.4 \\
5.8 \\
4.2 \\
4.8 \\
7.5 \\
6.2 \\
4.1 \\
3.9 \\
\end{array}$ & $\begin{array}{l}431 \\
414 \\
521 \\
466 \\
457 \\
340 \\
472 \\
373 \\
474 \\
323 \\
365 \\
252 \\
273 \\
400 \\
\end{array}$ \\
\hline \multicolumn{7}{|c|}{$\begin{array}{l}\text { aThe average annual percentage increase from } 1995 \text { to } 2005 . \\
\text { b Prisons and jails form one integrated system. Data include total jail and prison population. } \\
{ }^{c} \text { The incarceration rate includes an estimated } 6,200 \text { inmates sentenced to more than } 1 \text { year but } \\
\text { held in local jails or houses of corrections. } \\
{ }^{d} \text { Includes some inmates sentenced to } 1 \text { year or less. } \\
\text { epopulation figures based on custody counts. }\end{array}$} \\
\hline
\end{tabular}

Female prisoners increased $2.6 \%$ during 2005; male prisoners, $1.9 \%$

During 2005 the number of females under the jurisdiction of State or Federal prison authorities increased by $2.6 \%$ (table 5). The number of males in prison rose $1.9 \%$. At yearend 2005 , 107,518 females and $1,418,406$ males were in prison. Since 1995 the annual rate of growth in female prisoners averaged $4.6 \%$, which was higher than the $3.0 \%$ increase in male prisoners. By yearend 2005 females accounted for $7.0 \%$ of all prisoners, up from $6.1 \%$ in 1995 and $5.7 \%$ in 1990.

Relative to their number in the U.S. resident population, males were over 14 times more likely than females to be incarcerated in a State or Federal prison. At yearend 2005 there were 65 sentenced female inmates per 100,000 females in the resident population, compared to 929 sentenced male inmates per 100,000 males.

Since 1995 the total number of male prisoners has grown $34 \%$; the number of female prisoners, $57 \%$. At yearend 2005, 1 in every 1,538 women and 1 in every 108 men were incarcerated in a State or Federal prison.

Table 5. Number of prisoners under the jurisdiction of State or Federal correctional authorities, by gender, yearend 1995, 2004, and 2005

\begin{tabular}{lrr} 
& \multicolumn{1}{c}{ Males } & Females \\
\hline All inmates & & \\
2005 & $1,418,406$ & 107,518 \\
2004 & $1,392,278$ & 104,822 \\
1995 & $1,057,406$ & 68,468 \\
Percent change, & & \\
$\quad 2004-05$ & $1.9 \%$ & $2.6 \%$ \\
Average annual & & \\
$\quad$ change, 1995- & & \\
$\quad 2005$ & $3.0 \%$ & $4.6 \%$ \\
Sentenced to & & \\
more than 1 year & & \\
2005 & $1,362,530$ & 98,602 \\
2004 & $1,337,730$ & 95,998 \\
1995 & $1,021,059$ & 63,963 \\
Percent change, & & \\
$\quad 2004-05$ & $1.9 \%$ & $2.7 \%$ \\
Incarceration rate & & \\
2005 & 929 & 65 \\
2004 & 920 & 64 \\
1995 & 781 & 47 \\
\hline
\end{tabular}

${ }^{\star}$ The number of prisoners with a sentence of more than 1 year per 100,000 U.S. residents on December 31. 


\section{Over a third of female prisoners held in the 3 largest jurisdictions}

Texas $(13,506)$, the Federal system $(12,422)$, and California $(11,667)$ held more than a third of all female inmates at yearend (table 6). Oklahoma (129 sentenced female inmates per 100,000 female residents), Idaho (110), and Mississippi (107) had the highest female incarceration rates. States with the lowest female incarceration rates were concentrated in the Northeast, led by Rhode Island (with 10 sentenced female prisoners per 100,000 female residents), Massachusetts (12), and Maine (17).

Thirteen States had an average annual increase in the female prison population of more than $10 \%$ between 1995 and 2005, led by North Dakota (18.2\%), Idaho (14.1\%), and West Virginia $(14.0 \%)$. During this period the State female prison population increased an average of $4.5 \%$ per year; the Federal female prison population increased $5.3 \%$ per year.

\section{Privately operated prisons held $7.0 \%$ of State and Federal inmates in 2005}

Since yearend 2000 the number of Federal inmates held in private facilities increased $74.2 \%$, while the number held in State facilities increased $7.2 \%$. As a percentage of all inmates under State and Federal jurisdiction, the number held in private facilities has increased slightly to $7.0 \%$ in 2005 .

\begin{tabular}{rrrrr}
\multicolumn{4}{c}{$\begin{array}{c}\text { Number of inmates in } \\
\text { privately operated facilities }\end{array}$} & \multicolumn{2}{c}{$\begin{array}{c}\text { Percent of } \\
\text { prively }\end{array}$} \\
\cline { 2 - 4 } \multicolumn{1}{c}{ Total } & State & Federal & all inmates \\
\hline 2005 & 107,447 & 80,401 & 27,046 & $7.0 \%$ \\
2004 & 98,628 & 73,860 & 24,768 & 6.6 \\
2003 & 95,707 & 73,842 & 21,865 & 6.5 \\
2002 & 93,912 & 73,638 & 20,274 & 6.5 \\
2001 & 91,953 & 72,702 & 19,251 & 6.5 \\
2000 & 90,542 & 75,018 & 15,524 & 6.5
\end{tabular}

At yearend 2005, 33 States and the Federal system reported a total of 107,447 prisoners held in privately operated prison facilities (table 7). Private facilities held $6.0 \%$ of all State prisoners and $14.4 \%$ of Federal prisoners. Among States, Texas (with 17,517 State inmates housed in private facili-
Table 6. Female inmates under the jurisdiction of State or Federal correctional authorities, yearend 1995, 2004, and 2005

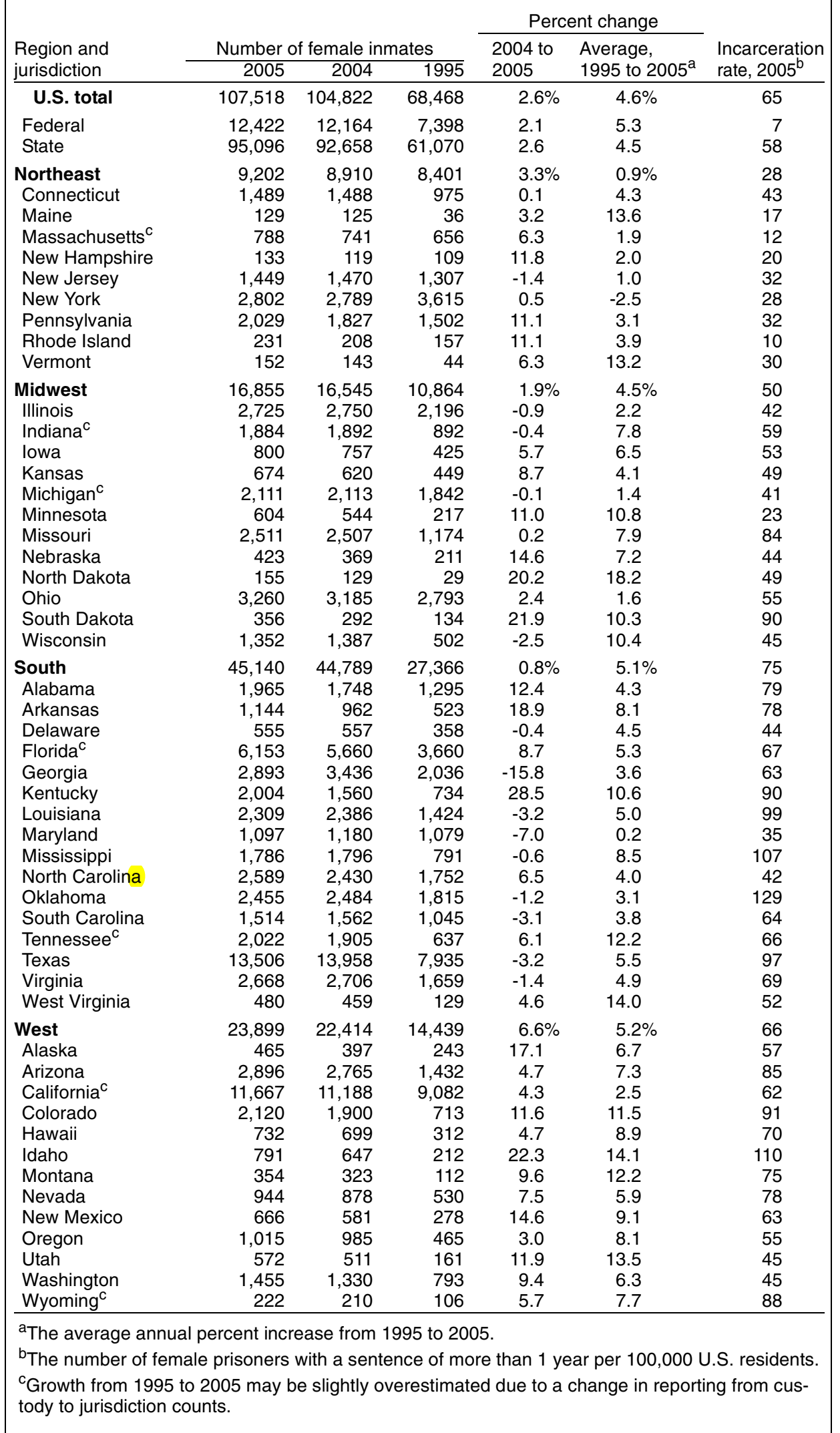


ties) and Florida (with 6,261) reported the largest populations in 2005.

Five States had at least $25 \%$ of their prison population housed in private prisons, led by New Mexico (43\%), Wyoming (41\%), Hawaii (31\%), Alaska (28\%), and Montana (26\%).

At yearend $2005,8.5 \%$ of State inmates in the South and $7.2 \%$ in the West were in privately operated facilities. The Northeast $(2.1 \%)$ and Midwest $(1.2 \%)$ had the lowest percentage of State inmates in private facilities.

\section{In 2005 local jails held almost $5 \%$ of State and Federal prisoners}

At the end of 2005, 35 States and the Federal system reported a total of 73,097 State and Federal prisoners held in local jails or other facilities operated by county or local authorities. These inmates held in local jails represented $4.8 \%$ of all prisoners in 2005 .

Louisiana had the largest percentage of its State inmate population housed in local jails (45\%). Four other states had at least a fifth of their population housed in local jails: Kentucky (29\%), Tennessee (27\%), West Virginia (24\%), and Mississippi (22\%).

Among State prisoners in the South, $10.0 \%$ were held in local jails. In the West, $2.1 \%$ of State prisoners were in local jails, and in the Midwest and Northeast both had $1.2 \%$ of their State prisoners in local jails.

From yearend 2000 to 2005 the number of Federal inmates held in local jails decreased by more than half, while the number of State inmates in local jails rose about $19 \%$.

\begin{tabular}{ccccc}
\multicolumn{5}{c}{$\begin{array}{l}\text { Number of State and Fed- } \\
\text { eral inmates held in local jails }\end{array}$} \\
\cline { 2 - 4 } & Total & State & Federal & all inmates \\
\hline 2005 & 73,097 & 72,053 & 1,044 & $4.8 \%$ \\
2004 & 74,445 & 73,246 & 1,199 & 5.0 \\
2003 & 73,440 & 70,162 & 3,278 & 5.0 \\
2002 & 72,550 & 69,173 & 3,377 & 5.0 \\
2001 & 70,681 & 67,760 & 2,921 & 5.0 \\
2000 & 63,140 & 60,702 & 2,438 & 4.5
\end{tabular}

Table 7. State and Federal prisoners held in private facilities or local jails, by jurisdiction, yearend 2004 and 2005

\begin{tabular}{|c|c|c|c|c|c|c|}
\hline \multirow[b]{2}{*}{$\begin{array}{l}\text { Region and } \\
\text { jurisdiction }\end{array}$} & \multicolumn{3}{|c|}{ Private facilities } & \multicolumn{3}{|c|}{ Local jails } \\
\hline & 2005 & 2004 & $\begin{array}{l}\text { Percent of } \\
\text { inmates }^{a}\end{array}$ & 2005 & 2004 & $\begin{array}{l}\text { Percent of } \\
\text { inmates }^{a}\end{array}$ \\
\hline U.S. total & 107,447 & 98,628 & $7.0 \%$ & 73,097 & 74,445 & $4.8 \%$ \\
\hline $\begin{array}{l}\text { Federal }^{b} \\
\text { State }\end{array}$ & $\begin{array}{l}27,046 \\
80,401\end{array}$ & $\begin{array}{l}24,768 \\
73,860\end{array}$ & $\begin{array}{r}14.4 \\
6.0\end{array}$ & $\begin{array}{r}1,044 \\
72,053\end{array}$ & $\begin{array}{r}1,199 \\
73,246\end{array}$ & $\begin{array}{l}0.6 \\
5.4\end{array}$ \\
\hline Northeast & 3,571 & 3,347 & $2.1 \%$ & 1,990 & 1,555 & $1.2 \%$ \\
\hline Connecticut & 0 & 0 & 0 & $\sim$ & $\sim$ & $\sim$ \\
\hline Maine & 20 & 32 & 1.0 & 0 & 0 & 0.0 \\
\hline Massachusetts & 0 & 0 & 0 & 212 & 236 & 2.0 \\
\hline New Hampshire & 0 & 0 & 0 & 13 & 9 & 0.5 \\
\hline New Jersey & 2,600 & 2,510 & 9.5 & 1,754 & 1,258 & 6.4 \\
\hline New York & 0 & 0 & 0 & 11 & 52 & 0.0 \\
\hline Pennsylvania & 503 & 366 & 1.2 & 0 & 0 & 0.0 \\
\hline Rhode Island & 0 & 0 & 0 & $\sim$ & $\sim$ & $\sim$ \\
\hline Vermont & 448 & 439 & 21.6 & $\sim$ & $\sim$ & $\sim$ \\
\hline Midwest & 3,030 & 3,477 & $1.2 \%$ & 3,171 & 3,267 & $1.2 \%$ \\
\hline Illinois & 0 & 0 & 0 & 0 & 0 & 0.0 \\
\hline Indiana & 115 & 641 & 0.5 & 1,695 & 2,024 & 6.9 \\
\hline lowa & 0 & 0 & 0 & 0 & 0 & 0.0 \\
\hline Kansas & 0 & 0 & 0 & 0 & 0 & 0.0 \\
\hline Michigan & 0 & 480 & 0 & 53 & 52 & 0.1 \\
\hline Minnesota & 760 & 307 & 8.2 & 674 & 484 & 7.3 \\
\hline Missouri & 0 & 0 & 0 & 0 & 0 & 0.0 \\
\hline Nebraska & 0 & 0 & 0 & 0 & 0 & 0.0 \\
\hline North Dakota & 47 & 35 & 3.4 & 45 & 43 & 3.2 \\
\hline Ohio & 2,075 & 1,929 & 4.5 & 0 & 0 & 0.0 \\
\hline South Dakota & 10 & 6 & 0.3 & 99 & 42 & 2.9 \\
\hline Wisconsin & 23 & 79 & 0.1 & 605 & 622 & 2.7 \\
\hline South & 51,823 & 48,267 & $8.5 \%$ & 60,621 & 62,966 & $10.0 \%$ \\
\hline Alabama & 320 & 244 & 1.1 & 2,281 & 1,645 & 8.2 \\
\hline Arkansas & 0 & 0 & 0 & 1,056 & 1,230 & 7.8 \\
\hline Delaware & 0 & 0 & 0 & $\sim$ & $\sim$ & $\sim$ \\
\hline Florida & 6,261 & 4,328 & 7.0 & 41 & 42 & 0.0 \\
\hline Georgia & 4,778 & 4,693 & 9.8 & 4,948 & 5,117 & 10.1 \\
\hline Kentucky & 2,224 & 1,746 & 11.3 & 5,674 & 5,084 & 28.9 \\
\hline Louisiana & 2,952 & 2,921 & 8.2 & 16,183 & 17,469 & 44.8 \\
\hline Maryland & 129 & 127 & 0.6 & 142 & 135 & 0.6 \\
\hline Mississippi & 4,779 & 4,744 & 23.3 & 4,426 & 4,624 & 21.6 \\
\hline North Carolina & 210 & 212 & 0.6 & 0 & 0 & 0.0 \\
\hline Oklahoma & 5,908 & 5,905 & 23.8 & 1,850 & 1,807 & 7.5 \\
\hline South Carolina & 14 & 6 & 0.1 & 384 & 429 & 1.7 \\
\hline Tennessee & 5,162 & 5,105 & 19.6 & 7,112 & 6,577 & 27.0 \\
\hline Texas & 17,517 & 16,668 & 10.4 & 10,569 & 13,228 & 6.3 \\
\hline Virginia & 1,569 & 1,568 & 4.4 & 4,679 & 4,502 & 13.2 \\
\hline West Virginia & 0 & 0 & 0 & 1,276 & 1,077 & 24.0 \\
\hline West & 21,977 & 18,769 & $7.2 \%$ & 6,271 & 5,458 & $2.1 \%$ \\
\hline Alaska & 1,365 & 1,392 & 28.4 & $\sim$ & $\sim$ & $\sim$ \\
\hline Arizona & 4,800 & 4,176 & 14.3 & 185 & 186 & 0.6 \\
\hline California & 2,801 & 2,989 & 1.6 & 2,518 & 2,452 & 1.5 \\
\hline Colorado & 4,039 & 2,819 & 18.8 & 393 & 638 & 1.8 \\
\hline Hawaii & 1,902 & 1,666 & 30.9 & $\sim$ & $\sim$ & $\sim$ \\
\hline Idaho & 1,596 & 1,263 & 23.4 & 569 & 133 & 8.3 \\
\hline Montana & 895 & 895 & 25.5 & 687 & 687 & 19.6 \\
\hline Nevada & 0 & 0 & 0 & 148 & 153 & 1.3 \\
\hline New Mexico & 2,843 & 2,686 & 43.3 & 122 & 0 & 1.9 \\
\hline Oregon & 0 & 0 & 0 & 48 & 18 & 0.4 \\
\hline Utah & 0 & 0 & 0 & 1,246 & 1,189 & 19.6 \\
\hline Washington & 890 & 327 & 5.1 & 332 & 1 & 1.9 \\
\hline Wyoming & 846 & 556 & 41.3 & 23 & 1 & 1.1 \\
\hline
\end{tabular}

$\sim$ Not applicable. Prison and jails form an integrated system.

${ }^{a}$ Based on the total number of inmates under State or Federal jurisdiction, by jurisdiction and region.

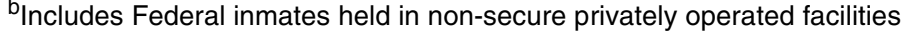
(7,065 in 2004 and 7,144 in 2005). 


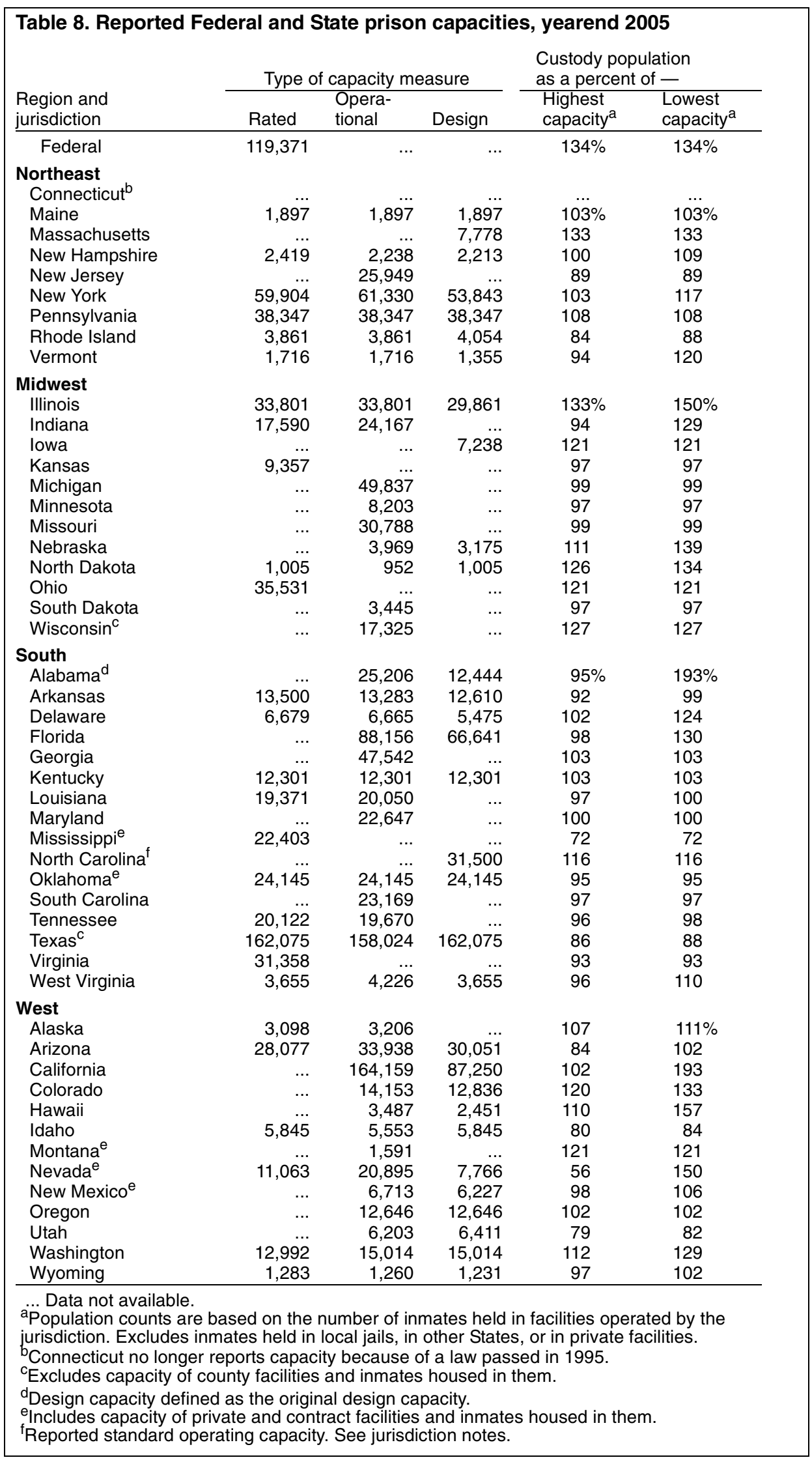

\section{States and the Federal system operated at or above highest capacity}

To estimate the capacity of their prisons, jurisdictions were asked to supply three measures for capacity at yearend 2005: rated, operational, and design capacities. These measures were defined as follows:

Rated capacity is the number of beds or inmates assigned by a rating official to institutions within the jurisdiction.

Operational capacity is the number of inmates that can be accommodated, based on a facility's staff, existing programs, and services.

Design capacity is the number of inmates that planners or architects intended for the facility.

Twenty-three jurisdictions gave only 1 measure or the same figure for each measure (table 8). For the 27 jurisdictions with more than 1 reported type of capacity, estimates of population as a percent of capacity are based on the highest and lowest figures provided.

At yearend 2005, 26 States reported that they were operating below $100 \%$ of their highest capacity, and 23 States and the Federal prison system reported operating at $100 \%$ or more of their highest capacity. Nevada, operating at $56 \%$ of its highest capacity,

\begin{tabular}{|c|c|}
\hline & State prisons \\
\hline $\begin{array}{l}\text { Highest capacity } \\
\text { Lowest capacity }\end{array}$ & $\begin{array}{l}1,212,576 \\
1,049,421\end{array}$ \\
\hline \multicolumn{2}{|c|}{$\begin{array}{l}\text { Population as a } \\
\text { percent of capacity* } \\
\text { Highest }\end{array}$} \\
\hline $\begin{array}{l}1995 \\
2000 \\
2001 \\
2002 \\
2003 \\
2004 \\
2005\end{array}$ & $\begin{array}{r}114 \\
100 \\
101 \\
101 \\
100 \\
99 \\
99\end{array}$ \\
\hline $\begin{array}{r}\text { Lowest } \\
1995 \\
2000 \\
2001 \\
2002 \\
2003 \\
2004 \\
2005\end{array}$ & $\begin{array}{l}125 \\
115 \\
116 \\
117 \\
116 \\
115 \\
114\end{array}$ \\
\hline $\begin{array}{l}{ }^{*} \text { Excludes prison } \\
\text { in privately opera } \\
\text { included in the re }\end{array}$ & $\begin{array}{l}\text { in local jails and } \\
\text { ities (unless } \\
\text { apacity). }\end{array}$ \\
\hline
\end{tabular}


reported the lowest percent of capacity occupied. Alabama and California, both $93 \%$ over their lowest reported capacity, had the highest percent of capacity occupied.

At yearend 2005 the Federal prison system was operating at 34\% over capacity. Overall, State prisons were operating between $99 \%$ of their highest capacity and $114 \%$ of their lowest capacity (table 9 ).

\section{$60 \%$ of State and Federal inmates black or Hispanic at yearend 2005}

At yearend 2005 black inmates represented an estimated $40 \%$ of all inmates with a sentence of more than 1 year, while white inmates accounted for $35 \%$ and Hispanic inmates, $20 \%$.

Although the total number of sentenced inmates rose sharply (up 35\% between 1995 and 2005), there were small changes in the racial and Hispanic composition of the inmate population.

At yearend 2005, black males $(547,200)$ outnumbered white males $(459,700)$ and Hispanic males $(279,000)$ among inmates with a sentence of more than 1 year (table 10). About $40 \%$ of all male inmates sentenced to more than 1 year were black.

\begin{tabular}{|c|c|c|}
\hline & \multicolumn{2}{|c|}{$\begin{array}{l}\text { Percent of State or } \\
\text { Federal prisoners }^{\text {a }}\end{array}$} \\
\hline & 1995 & 2005 \\
\hline Total & $100 \%$ & $100 \%$ \\
\hline Hispanic & 17.6 & 20.2 \\
\hline \multicolumn{3}{|l|}{ One race ${ }^{b}$} \\
\hline White & 33.5 & 34.6 \\
\hline Black & 45.7 & 39.5 \\
\hline Other races & 3.2 & 2.7 \\
\hline Two or more races ${ }^{b}$ & - & 3.0 \\
\hline \multicolumn{3}{|c|}{$\begin{array}{l}\text { a Based on jurisidiction counts of inmates with } \\
\text { sentence of more than } 1 \text { year. }\end{array}$} \\
\hline
\end{tabular}

Table 10. Number of sentenced prisoners under State or Federal jurisdiction, by gender, race, Hispanic origin, and age, yearend 2005

\begin{tabular}{|c|c|c|c|c|c|c|c|c|}
\hline \multirow[b]{3}{*}{$\underline{\text { Age }}$} & \multicolumn{8}{|c|}{ Number of sentenced prisoners } \\
\hline & \multicolumn{4}{|c|}{ Males } & \multicolumn{4}{|c|}{ Females } \\
\hline & Total $^{\mathrm{a}}$ & White $^{\mathrm{b}}$ & Black $^{b}$ & Hispanic & Total $^{\mathrm{a}}$ & White $^{b}$ & Black $^{b}$ & Hispanic \\
\hline Total & $1,362,500$ & 459,700 & 547,200 & 279,000 & 98,600 & 45,800 & 29,900 & 15,900 \\
\hline $18-19$ & 26,300 & 7,200 & 11,800 & 5,600 & 1,200 & 500 & 400 & 200 \\
\hline $20-24$ & 218,700 & 62,700 & 94,200 & 50,400 & 11,900 & 5,300 & 3,600 & 2,300 \\
\hline $25-29$ & 244,800 & 67,000 & 106,600 & 59,600 & 15,300 & 6,700 & 4,700 & 2,900 \\
\hline $30-34$ & 224,200 & 69,800 & 92,000 & 51,100 & 17,400 & 8,100 & 5,100 & 2,900 \\
\hline $35-39$ & 207,200 & 72,300 & 81,600 & 41,600 & 19,400 & 9,000 & 6,000 & 3,000 \\
\hline $40-44$ & 185,200 & 70,900 & 71,000 & 31,600 & 16,500 & 7,800 & 5,100 & 2,400 \\
\hline $45-54$ & 189,800 & 76,300 & 71,100 & 29,500 & 13,800 & 6,500 & 4,300 & 1,800 \\
\hline 55 or older & 63,500 & 32,900 & 17,600 & 9,000 & 3,000 & 1,800 & 700 & 300 \\
\hline
\end{tabular}

Note: Based on estimates by gender, race, Hispanic origin, and age from the 2004 Survey of Inmates in State Correctional Facilities and updated from jurisdiction counts by gender at yearend 2005. Estimates were rounded to the nearest 100. See Methodology for details.

ancludes American Indians, Alaska Natives, Asians, Native Hawaiians, other Pacific Islanders, and persons identifying two or more races.

${ }^{b}$ Excludes Hispanics and persons identifying two or more races.

Table 11. Number of sentenced prisoners under State or Federal jurisdiction per 100,000 residents, by gender, race, Hispanic origin, and age, yearend 2005

Number of sentenced prisoners per 100,000 residents

\begin{tabular}{|c|c|c|c|c|c|c|c|c|}
\hline \multirow[b]{2}{*}{ Age } & \multicolumn{4}{|c|}{ Males } & \multicolumn{4}{|c|}{ Females } \\
\hline & Total $^{\mathrm{a}}$ & White $^{b}$ & Black $^{b}$ & Hispanic & Total $^{\mathrm{a}}$ & White $^{\mathrm{b}}$ & Black $^{b}$ & Hispanic \\
\hline Total & 929 & 471 & 3,145 & 1,244 & 65 & 45 & 156 & 76 \\
\hline $18-19$ & 619 & 274 & 1,920 & 791 & 29 & 20 & 61 & 38 \\
\hline $20-24$ & 2,016 & 948 & 6,345 & 2,493 & 118 & 85 & 248 & 137 \\
\hline $25-29$ & 2,342 & 1,098 & 8,082 & 2,618 & 153 & 113 & 339 & 158 \\
\hline $30-34$ & 2,234 & 1,172 & 7,726 & 2,450 & 177 & 138 & 391 & 165 \\
\hline $35-39$ & 1,953 & 1,067 & 6,630 & 2,255 & 185 & 134 & 435 & 184 \\
\hline $40-44$ & 1,641 & 923 & 5,472 & 1,975 & 145 & 102 & 345 & 164 \\
\hline $45-54$ & 899 & 493 & 3,136 & 1,327 & 63 & 41 & 163 & 85 \\
\hline 55 or older & 208 & 135 & 697 & 416 & 8 & 6 & 19 & 13 \\
\hline
\end{tabular}

Note: Based on estimates of the U.S resident population on January 1, 2006, by gender, race, Hispanic origin, and age. Detailed categories exclude persons identifying with two or more races. ancludes American Indians, Alaska Natives, Asians, Native Hawaiians, other Pacific Islanders, and persons identifying two or more races.

${ }^{b}$ Excludes Hispanics and persons identifying two or more races.
Comparisons with previous estimates of inmates by race and Hispanic origin are constrained by new collection methodologies. Following guidelines provided by the Office of Management and Budget, estimates in 2005 were made separately for persons identifying with one race $(97 \%)$ and those identifying with two or more races (3\%). Adoption of these guidelines reduced the number and percent of inmates identified as non-Hispanic white and black.

\section{An estimated $8 \%$ of black males, age 25 to 29 in prison in 2005}

When incarceration rates are estimated separately by age group, black males in their twenties and thirties are found to have high rates relative to other groups (table 11). Expressed in terms of percentages, $8.1 \%$ of black males age 25 to 29 were in prison on December 31, 2005, compared to $2.6 \%$ of Hispanic males and about $1.1 \%$ of white males in the same age group.

Although incarceration rates drop with age, the percentage of black males age 45 to 54 in prison at yearend 2005 was $3.1 \%-$ a rate higher than the highest rate among Hispanic males (2.6\% for those age 25 to 29 ), and more than twice the highest rate among white males $(1.2 \%$ for those age 30 to 34 ).

Female incarceration rates, though substantially lower than male incarceration rates at every age, reveal similar racial and ethnic differences. Black females (with an incarceration rate of 156 per 100,000$)$ were more than twice as likely as Hispanic females (76 per 100,000) and over 3 times more likely than white females (45 per $100,000)$ to have been in prison on December 31, 2005. These differences among white, black, and Hispanic females were consistent across all age groups. 


\section{Half of State prisoners were violent offenders}

In absolute numbers an estimated 650,400 inmates in State prison at yearend 2003 (the latest available offense data) were held for violent offenses: 151,500 for murder, 176,600 for robbery, 124,200 for assault, and 148,800 for rape and other sexual assaults (table 12). In addition, 262,000 inmates were held for property offenses, 250,900 for drug offenses, and 86,400 for public-order offenses.

Overall, the proportion of violent offenders increased from $47 \%$ in 1995 to $52 \%$ in 2003 . Property offenders decreased from about $23 \%$ in 1995 to $21 \%$ in 2003; drug offenders decreased from $22 \%$ to $20 \%$.

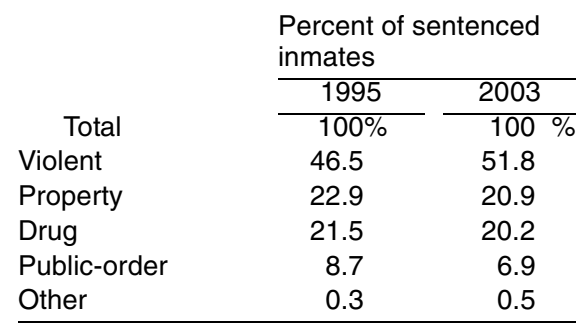

Offenses of State prisoners varied by gender, race, and Hispanic origin

More than half $(53 \%)$ of male State prisoners were serving time for a violent offense in 2003, compared to around a third (35\%) of female prisoners (table 13). Females were more likely than males to be serving time for property offenses (30\% compared to $20 \%$ ) and drug offenses (29\% compared to $19 \%$ ).

Offense types also varied by race and Hispanic origin. Approximately half of white, black, and Hispanic State inmates were violent offenders. White prisoners were more likely to be serving time for a property offense $(27 \%)$, compared to blacks (18\%) and Hispanics (17\%). Nearly a quarter of black State inmates (24\%) and Hispanic inmates $(23 \%)$ were drug offenders, compared to a seventh of white inmates (14\%).
Table 12. Estimated number of sentenced prisoners under State jurisdiction, by offense, gender, race, and Hispanic origin, yearend 2003

\begin{tabular}{|c|c|c|c|c|c|c|}
\hline Offense & All inmates & Male & Female & White ${ }^{a}$ & Black $^{\mathrm{a}}$ & Hispanic \\
\hline Total & $1,256,400$ & $1,173,600$ & 82,800 & 453,400 & 562,100 & 219,200 \\
\hline $\begin{array}{l}\text { Violent offenses } \\
\text { Murder }^{\mathrm{b}} \\
\text { Manslaughter } \\
\text { Rape } \\
\text { Other sexual assault } \\
\text { Robbery } \\
\text { Assault } \\
\text { Other violent }\end{array}$ & $\begin{array}{r}650,400 \\
151,500 \\
17,700 \\
61,300 \\
87,500 \\
176,600 \\
124,200 \\
31,700\end{array}$ & $\begin{array}{r}621,600 \\
142,800 \\
15,900 \\
60,800 \\
86,300 \\
169,600 \\
116,900 \\
29,300\end{array}$ & $\begin{array}{r}28,800 \\
8,700 \\
1,800 \\
500 \\
1,200 \\
7,000 \\
7,300 \\
2,400\end{array}$ & $\begin{array}{r}227,100 \\
46,900 \\
7,100 \\
31,500 \\
49,300 \\
39,500 \\
40,000 \\
12,700\end{array}$ & $\begin{array}{r}294,000 \\
72,200 \\
7,600 \\
21,900 \\
20,000 \\
106,300 \\
53,400 \\
12,600\end{array}$ & $\begin{array}{r}116,600 \\
28,600 \\
2,600 \\
6,700 \\
16,600 \\
28,300 \\
28,100 \\
5,600\end{array}$ \\
\hline $\begin{array}{l}\text { Property offenses } \\
\text { Burglary } \\
\text { Larceny } \\
\text { Motor vehicle theft } \\
\text { Fraud } \\
\text { Other property }\end{array}$ & $\begin{array}{r}262,000 \\
137,600 \\
49,000 \\
20,600 \\
30,400 \\
24,400\end{array}$ & $\begin{array}{r}237,100 \\
132,100 \\
41,200 \\
19,500 \\
21,700 \\
22,600\end{array}$ & $\begin{array}{r}24,900 \\
5,500 \\
7,800 \\
1,100 \\
8,700 \\
1,800\end{array}$ & $\begin{array}{r}120,100 \\
61,000 \\
21,900 \\
8,200 \\
16,700 \\
12,300\end{array}$ & $\begin{array}{r}100,700 \\
53,600 \\
20,400 \\
7,000 \\
11,100 \\
8,600\end{array}$ & $\begin{array}{r}37,200 \\
21,000 \\
6,000 \\
4,900 \\
2,100 \\
3,100\end{array}$ \\
\hline Drug offenses & 250,900 & 226,800 & 24,100 & 64,800 & 133,100 & 50,100 \\
\hline Public-order offense & 86,400 & 82,000 & 4,400 & 38,500 & 31,800 & 14,100 \\
\hline Other/unspecified $^{d}$ & 6,800 & 6,200 & 600 & 2,900 & 2,500 & 1,200 \\
\hline
\end{tabular}

Note: Data are for inmates with a sentence of more than 1 year under the jurisdiction of State correctional authorities. The numbers of inmates by gender were based on jurisdiction counts at yearend (NPS-1); numbers by race and Hispanic origin were based on data from the 2004 Survey of Inmates in State Correctional Facilities; and numbers within each category by offense were estimated using the National Corrections Reporting Program, 2003.

All estimates were rounded to the nearest 100. Detail may not add to total due to rounding.

aExcludes Hispanics.

$\mathrm{b}_{\text {Includes nonnegligent manslaughter. }}$

cIncludes weapons, drunk driving, court offenses, commercialized vice, morals and decency charges, liquor law violations, and other public-order offenses.

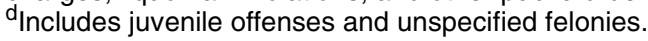

Table 13. Estimated percent of sentenced prisoners under State jurisdiction, by offense, gender, race, and Hispanic origin, yearend 2003

\begin{tabular}{|c|c|c|c|c|c|c|}
\hline Offense & All inmates & Male & Female & White $^{\mathrm{a}}$ & Black $^{a}$ & Hispanic \\
\hline Total & $100 \%$ & $100 \%$ & $100 \%$ & $100 \%$ & $100 \%$ & $100 \%$ \\
\hline Violent offenses & $51.8 \%$ & $53.0 \%$ & $34.8 \%$ & $50.1 \%$ & $52.3 \%$ & $53.2 \%$ \\
\hline Murder ${ }^{b}$ & 12.1 & 12.2 & 10.5 & 10.4 & 12.8 & 13.0 \\
\hline Manslaughter & 1.4 & 1.4 & 2.2 & 1.6 & 1.4 & 1.2 \\
\hline Rape & 4.9 & 5.2 & 0.6 & 7.0 & 3.9 & 3.1 \\
\hline Other sexual assault & 7.0 & 7.4 & 1.4 & 10.9 & 3.6 & 7.6 \\
\hline Robbery & 14.1 & 14.4 & 8.4 & 8.7 & 18.9 & 12.9 \\
\hline Assault & 9.9 & 10.0 & 8.8 & 8.8 & 9.5 & 12.8 \\
\hline Other violent & 2.5 & 2.5 & 2.9 & 2.8 & 2.2 & 2.5 \\
\hline Property offenses & $20.9 \%$ & $20.2 \%$ & $30.0 \%$ & $26.5 \%$ & $17.9 \%$ & $17.0 \%$ \\
\hline Burglary & 11.0 & 11.3 & 6.6 & 13.5 & 9.5 & 9.6 \\
\hline Larceny & 3.9 & 3.5 & 9.4 & 4.8 & 3.6 & 2.7 \\
\hline Motor vehicle theft & 1.6 & 1.7 & 1.3 & 1.8 & 1.3 & 2.3 \\
\hline Fraud & 2.4 & 1.8 & 10.5 & 3.7 & 2.0 & 1.0 \\
\hline Other property & 1.9 & 1.9 & 2.2 & 2.7 & 1.5 & 1.4 \\
\hline Drug offenses & $20.0 \%$ & $19.3 \%$ & $29.1 \%$ & $14.3 \%$ & $23.7 \%$ & $22.9 \%$ \\
\hline Public-order offenses ${ }^{c}$ & $6.9 \%$ & $7.0 \%$ & $5.3 \%$ & $8.5 \%$ & $5.7 \%$ & $6.4 \%$ \\
\hline Other/unspecified $^{d}$ & $0.5 \%$ & $0.5 \%$ & $0.8 \%$ & $0.6 \%$ & $0.4 \%$ & $0.5 \%$ \\
\hline
\end{tabular}

Note: Data are for inmates with a sentence of more than 1 year under the jurisdiction of State correctional authorities. Detail may not add to total due to rounding.

axcludes Hispanics.

${ }^{\mathrm{b}}$ Includes nonnegligent manslaughter.

${ }^{\mathrm{c}}$ Includes weapons, drunk driving, court offenses, commercialized vice, morals and decency charges, liquor law violations, and other public-order offenses.

$\mathrm{d}_{\text {Includes juvenile offenses and unspecified felonies. }}$ 
Changing Federal prison population related to drug and immigration offenses

Prisoners sentenced for drug offenses constitute the largest group of Federal inmates (55\%) in 2003, down from $60 \%$ in 1995 (table 14). On September 30,2003 , the date of the latest available data in the Federal Justice Statistics Program, Federal prisons held 86,972 sentenced drug offenders, compared to 52,782 at yearend 1995 .

Between 1995 and 2003 the number of Federal inmates held for public-order offenses increased $170 \%$, most of which was accounted for by the increase in immigration offenses (up $394 \%$ ). The number of immigration offenders rose from 3,420 in 1995 to 16,903 in 2003. Immigration violators represented over $10 \%$ of Federal inmates in 2003.

The number of weapons offenders held in Federal prisons increased about $120 \%$ (from 7,446 to 16,377 ) between 1995 and 2003. Weapons offenders represented about $10 \%$ of the Federal inmate population in 2003.
Violent offenders under Federal jurisdiction increased 46\% from 1995 to 2003 , and accounted for almost $8 \%$ of the total growth during the period.

Homicide offenders increased 146\%, from 1,068 in 1995 to 2,632 in 2003.

\begin{tabular}{|c|c|c|c|c|c|}
\hline \multirow[b]{2}{*}{ Offense } & \multicolumn{3}{|c|}{$\begin{array}{l}\text { Number of sentenced inmates } \\
\text { in Federal prisons }\end{array}$} & \multirow{2}{*}{$\begin{array}{l}\text { Percent } \\
\text { change, } \\
1995-2003\end{array}$} & \multirow{2}{*}{$\begin{array}{l}\text { Percent of } \\
\text { total growth, } \\
1995-2003\end{array}$} \\
\hline & 2003 & 2000 & 1995 & & \\
\hline Total & 158,426 & 131,739 & 88,658 & $78.7 \%$ & $100 \%$ \\
\hline $\begin{array}{l}\text { Violent offenses } \\
\text { Homicide }^{\mathrm{a}} \\
\text { Robbery } \\
\text { Other violent }\end{array}$ & $\begin{array}{r}16,688 \\
2,632 \\
10,398 \\
3,658\end{array}$ & $\begin{array}{r}13,740 \\
1,363 \\
9,712 \\
2,665\end{array}$ & $\begin{array}{r}11,409 \\
1,068 \\
8,377 \\
1,964\end{array}$ & $\begin{array}{c}46.3 \% \\
146.4 \\
24.1 \\
86.3\end{array}$ & $\begin{array}{l}7.6 \% \\
2.2 \\
2.9 \\
2.4\end{array}$ \\
\hline $\begin{array}{l}\text { Property offenses } \\
\text { Burglary } \\
\text { Fraud } \\
\text { Other property }\end{array}$ & $\begin{array}{r}11,283 \\
567 \\
8,241 \\
2,475\end{array}$ & $\begin{array}{r}10,135 \\
462 \\
7,506 \\
2,167\end{array}$ & $\begin{array}{r}7,842 \\
177 \\
5,823 \\
1,842\end{array}$ & $\begin{array}{l}43.9 \% \\
220.3 \\
41.5 \\
34.4\end{array}$ & $\begin{array}{l}4.9 \% \\
0.6 \\
3.5 \\
0.9\end{array}$ \\
\hline Drug offenses & 86,972 & 74,276 & 52,782 & $64.8 \%$ & $49 \%$ \\
\hline $\begin{array}{l}\text { Public-order } \\
\text { Immigration } \\
\text { Weapons } \\
\text { Other }\end{array}$ & $\begin{array}{r}42,325 \\
16,903 \\
16,377 \\
9,045\end{array}$ & $\begin{array}{r}32,325 \\
13,676 \\
10,822 \\
7,827\end{array}$ & $\begin{array}{r}15,655 \\
3,420 \\
7,446 \\
4,789\end{array}$ & $\begin{array}{l}170.4 \% \\
394.2 \\
119.9 \\
88.9\end{array}$ & $\begin{array}{l}38.2 \% \\
19.3 \\
12.8 \\
6.1\end{array}$ \\
\hline Other/unspecified $^{\mathbf{b}}$ & 1,158 & 1,263 & 970 & $19.4 \%$ & $0.3 \%$ \\
\hline
\end{tabular}

Note: All data are from the BJS Federal justice database. Data are for September 30 and based on sentenced inmates, regardless of sentence length.

a Includes murder, nonnegligent manslaughter, and negligent manslaughter.

$\mathrm{b}_{\text {Includes offenses not classified. }}$
While the number of offenders in each major offense category increased, the number incarcerated for a drug offense accounted for the largest percentage of the total growth (49\%), followed by public-order offenders (38\%).

The number of Immigration and Customs Enforcement detainees increased 2.6\% during 2005

The U.S. Bureau of Immigration and Customs

Enforcement (ICE) reported 19,562 detainees on

December 31, 2005, up from 19,057 at yearend 2004.

Nearly two-thirds of these detainees $(12,509)$ were held in

Federal or State prisons and local jails. About a fifth were

held in ICE-operated facilities $(3,782)$ and private facilities under exclusive contract to ICE $(2,365)$.

The number of detainees under ICE jurisdiction more than doubled between 1995 and 2005. This increase most affected State prisons, local jails, and other facilities maintaining intergovernmental agreements with ICE. These facilities held 12,509 detainees in 2005, up from 2,286 in 1995.

Among the 19,562 detainees held for immigration violations at yearend 2005, 10,153 had been convicted of criminal offenses, and 1,583 had pending criminal cases (not shown in table). Detainees convicted of violent offenses (28.0\%) and drug offenses (28.7\%) constituted the largest groups under ICE jurisdiction, followed by public-order offenses (19.2\%) and property offenses (15.3\%).

Detainees under the jurisdiction of the Bureau of Immigration and Customs Enforcement (ICE), by type of facility, yearend 1995, 2004, and 2005

\begin{tabular}{lrrrr} 
& \multicolumn{3}{c}{ Number of detainees } & \multirow{2}{*}{$\begin{array}{c}\text { Percent } \\
\text { change, }\end{array}$} \\
\cline { 2 - 4 } Facility type & 2005 & 2004 & 1995 & $2004-05$ \\
\hline$\quad$ Total & 19,562 & 19,057 & 8,177 & $2.6 \%$ \\
ICE-operated facilities & 3,782 & 4,545 & 3,776 & -16.8 \\
Private facilities under exclusive & & & & \\
$\quad$ contract to ICE & 2,365 & 1,678 & 652 & 40.9 \\
Federal Bureau of Prisons & 860 & 1,214 & 1,282 & -29.2 \\
Other Federal facilities & 46 & 50 & 181 & -8.0 \\
Intergovernmental agreements & 12,509 & 11,570 & 2,286 & $8.1 \%$ \\
$\quad$ State prisons & 276 & 178 & 8 & 55.1 \\
Local jails & 8,322 & 7,877 & 1,984 & 5.6 \\
Other facilities & 3,911 & 3,515 & 294 & 11.3
\end{tabular}




\section{Number of prisoners held by military authorities up 6.7\% during 2005}

There were 2,322 prisoners under military jurisdiction at yearend 2005. Fifty-eight percent of the prisoners held by the Army, Air Force, Navy, Marine Corps, and Coast Guard had a sentence of 1 year or more. At yearend 2005 the Army's disciplinary barracks, Fort

Leavenworth, Kansas, and six other local or regional Army facilities held the largest share of inmates under military jurisdiction (41\%). The 6 Marine Corps facilities held $23 \%$ of all inmates; the 34 Air Force facilities held $18 \%$ of all inmates; and the 11 Navy facilities held $17 \%$ of all inmates.

The operational capacity of the 58 military confinement facilities was 3,286 (not shown in table). At yearend 2005 these facilities were operating at $71 \%$ of their operational capacity. About $87 \%$ of prisoners held by the Army, Air Force, Navy, and Marine Corps were convicted inmates; $13 \%$ were unconvicted.
Prisoners under military jurisdiction, by branch of service, yearend 2004 and 2005

\begin{tabular}{|c|c|c|c|c|}
\hline$h$ of & Tota & $\begin{array}{l}\text { Percent } \\
\text { change, }\end{array}$ & $\begin{array}{l}\text { Sentenced to } \\
\text { more than } 1 \text { year }\end{array}$ & $\begin{array}{l}\text { Percent } \\
\text { change, }\end{array}$ \\
\hline ervice & 20 & 2004-05 & & \\
\hline
\end{tabular}

\section{To which prisoners}

belonged

Total

Air Force

Army

Marine Corps

Navy

Coast Guard

Holding prisoners

Total

Air Force

Army

Marine Corps

Navy

$\begin{array}{rr}2,322 & 2,177 \\ 422 & 400 \\ 949 & 853 \\ 527 & 495 \\ 406 & 409 \\ 18 & 20 \\ & \\ 2,322 & 2,177 \\ 120 & 109 \\ 1,059 & 998 \\ 470 & 416 \\ 673 & 654\end{array}$

$6.7 \%$
5.5
11.3
6.5
-0.7
-10.0

$6.7 \%$
10.1
6.1
13.0
2.9

$\begin{array}{rrc}1,340 & 1,295 & 3.5 \% \\ 258 & 243 & 6.2 \\ 638 & 614 & 3.9 \\ 209 & 241 & -13.3 \\ 223 & 188 & 18.6 \\ 12 & 9 & 33.3 \\ & & \\ 1,340 & 1,295 & 3.5 \% \\ 24 & 11 & 118.2 \\ 818 & 811 & 0.9 \\ 133 & 153 & -13.1 \\ 365 & 320 & 14.1\end{array}$

\section{Methodology}

\section{National Prisoner Statistics}

The Bureau of Justice Statistics (BJS), with the U.S. Census Bureau as its collection agent, obtains yearend and midyear counts of prisoners from departments of correction in each of the 50 States and the Federal Bureau of Prisons.

The National Prisoner Statistics (NPS) distinguishes prisoners in custody from those under jurisdiction. To have custody of a prisoner, a State must hold that person in one of its facilities. To have jurisdiction means that a State has legal authority over the prisoner. Prisoners under a State's jurisdiction may be in the custody of a local jail, another State's prison, or other correctional facilities. Some States are unable to provide both custody and jurisdiction counts.

Excluded from NPS counts are persons confined in locally administered confinement facilities who are under the jurisdiction of local authorities. NPS counts include all inmates in Stateoperated facilities in Alaska, Connecticut, Delaware, Hawaii, Rhode Island, and Vermont, which have combined jail-prison systems. NPS excludes inmates held by the District of Columbia (DC), which as of yearend 2001 operated only a jail system.

\section{Military Corrections Statistics}

BJS obtains yearend counts of prisoners in the custody of U.S. military authorities from the Department of Defense Corrections Council. In 1994 the council, comprised of representatives from each branch of military service, adopted a standardized report (DD Form 2720) with a common set of items and definitions. This report gives data on persons held in U.S. military confinement facilities inside and outside the continental United States, by branch of service, gender, race, Hispanic origin, conviction status, sentence length, and offense. It also has data on the number of facilities, their design, and rated capacities.

\section{Other inmate counts}

In 1995 BJS began collecting yearend counts of prisoners from the departments of correction in the U.S. Territories (American Samoa, Guam, and U.S. Virgin Islands) and U.S. Commonwealths (Northern Mariana Islands and Puerto Rico). These counts include all inmates for whom the Territory or Commonwealth government had legal authority (inmates under jurisdiction) and all inmates physically located in prison or jail facilities (inmates in custody). These counts are collected by gender, race, Hispanic origin, and sentence length. In addition, BJS obtains reports of the total design, rated, and operational capacity of correctional facilities.

\section{Estimating age-specific incarceration rates}

The number of sentenced prisoners within each group was estimated for men, women, whites, blacks, and Hispanics. In 2005 estimates were produced separately for inmates under State jurisdiction by combining data by gender from NPS and data by race and Hispanic origin from the 2004 Survey of Inmates in State Correctional Facilities.

The Federal Justice Statistics Program (FJSP) provided counts of sentenced Federal inmates by age for each demographic group at the end of fiscal year 2003. The NPS provided counts of sentenced Federal inmates by gender at yearend 2005 and counts by race and Hispanic origin at midyear 2005. The FJSP counts were converted to percentages and multiplied by the NPS totals at yearend 2005 . 
Washington, DC 20531

Official Business

Penalty for Private Use $\$ 300$

Estimates of the U.S. resident population for January 1, 2006, by age, gender, race and Hispanic origin were obtained from the U.S. Census Bureau. Age-specific rates of incarceration for each demographic group were calculated by dividing the estimated number of sentenced prisoners in each age group by the number of U.S. residents in each age group and then multiplying by 100,000 . Detailed categories exclude persons identifying with two or more races. Totals by gender include all inmates and U.S. residents, regardless of racial identification.
This report in portable document format and in ASCII and its related statistical data and tables are available at the BJS World Wide Web Internet site: <http:// www.ojp.usdoj.gov/bjs/abstract/ p05.htm>

\section{Office of Justice Programs}

Partnerships for Safer Communities http://www.ojp.usdoj.gov
The Bureau of Justice Statistics is the statistical agency of the U.S. Department of Justice. Jeffrey L. Sedgwick is director.

BJS Bulletins present the first release of findings from permanent data collection programs.

This Bulletin was written by Paige M. Harrison and Allen J. Beck. Todd M. Minton verified the report. Tina Dorsey and Carolyn Williams edited the report, under the supervision of Doris J. James. Jayne Robinson prepared the report for final printing.

November 2006, NCJ 215092 


\section{NPS jurisdiction notes}

Alaska - Prisons and jails form one integrated system. All NPS data include jail and prison populations. Counts exclude individuals in electronic and special monitoring programs.

Arizona - Population counts are based on custody data. Counts exclude 64 sentenced inmates housed in contracted local jail facilities, some awaiting transfer to the DOC.

Inmates held in other States are excluded from counts.

California - Population counts include felons and civil addicts who are temporarily absent, such as in court, jail or hospital.

Colorado - Population counts include 207 male and 11 female inmates in the Youthful Offender System.

Capacity figures exclude 6 privately run facilities under contract with the Department of Corrections.

Connecticut - Prisons and jails form one integrated system. All NPS data include jail and prison populations.

Legislation in 1995 abolished the capacity law so that prisons no longer have a rated or operational capacity. Design capacity is recorded separately in each facility.

Delaware - Prisons and jails form one integrated system. All NPS data include jail and prison populations. Jurisdiction counts exclude inmates housed in facilities in other States.

Capacity counts include Department of Correction halfway houses.

Federal - Custody counts include inmates housed in privately operated secure facilities under contract with BOP or with State or local government that has an intergovernmental agreement. Custody counts exclude offenders under home confinement.

Rated capacity excludes contract beds.

Georgia - Population counts are based on custody data, including inmates in privately operated facilities.

Facilities in Georgia are not given rated or design capacities.

Hawaii - Prisons and jails form one integrated system. All NPS data include jail and prison populations.

Idaho - Rated capacity is defined as $100 \%$ of the maximum capacity; operational capacity as $95 \%$ of the maximum
Illinois - Population counts are based on jurisdiction data. Counts of inmates with a sentence of more than 1 year include an undetermined number with a sentence of 1 year.

lowa - Population counts are based on custody data. Counts of inmates with a sentence of more than 1 year include an undetermined number with a sentence of 1 year or less.

Kansas - Population counts of inmates with a sentence of more than 1 year include an undetermined number with a sentence of 1 year or less.

Louisiana - Counts are as of December 28,2005 . Counts include 16,069 males and 1,400 females housed in local jails as a result of a partnership with the Louisiana Sheriffs' Association and local authorities.

Massachusetts - By law, offenders may be sentenced to terms of up to $21 / 2$ years in locally operated jails. Such offenders are included in counts and rates for local jails. About 6,200 inmates with sentences of more than 1 year were held in local jails in 2005.

Michigan - Operational capacity includes institution and camp net capacities and populations in community programs.

Minnesota - Counts include inmates housed in local jails, on work release or community work programs, or housed in a private contract facility.

Mississippi - Operation and design capacities include private prison capacities.

Missouri - Design capacities are not available for older prisons. Operational capacity is defined as the number of available beds including those temporarily off-line.

Montana - Capacity figures include 2 county operated regional prisons (an estimated 300 beds), 1 private prison (500 beds), and a State operated boot camp (60 beds).

Nebraska - Operational capacity is defined as stress capacity (or $125 \%$ of design capacity), which is ordered by the governor and set by the Department of Corrections.

Nevada - Rated capacity is defined as emergency capacity. Design capacity is defined as one bed per cell.

New Jersey - Population counts of inmates with a sentence of more than 1 year include an undetermined number with a sentence of 1 year.
North Carolina - Capacity figures refer to standard operating capacity, based on single occupancy per cell and 50 square feet per inmate in multiple occupancy units.

Ohio - Population counts of inmates with a sentence of more than 1 year include an undetermined number with a sentence of 1 year or less.

Oklahoma - Population counts exclude inmates awaiting transfer in local jails.

Capacity figures include private prisons and contract jails.

Oregon - Inmates with under a 1 year maximum sentence remain under the control of local counties.

Rhode Island - Prisons and jails form one integrated system. All NPS data include jail and prison populations.

South Carolina - Population counts include 25 inmates who were unsentenced, under safekeeping, or ICE status.

South Dakota - Operational capacity is planned capacity. Rated and design capacities are not recognized.

Tennessee - Population counts of inmates with a sentence of more than 1 year include an undetermined number with a sentence of 1 year.

Texas - Jurisdiction counts include inmates serving time in a pre-parole transfer (PPT) or intermediary sanctions facility (ISF), substance abuse felony punishment facility (SAFPF), temporary releases to counties, and paper-ready inmates in local jails.

Capacity figures include public, privately operated, and county contracted facilities that are State funded. Non-contracted county jail beds are excluded.

Vermont - Prisons and jails form one integrated system. All NPS data include jail and prison populations.

Virginia - Rated capacity is the DOC count of beds, which takes into account the number of inmates that can be accommodated based on staff, programming, services, and design.

Washington - A recently revised law allows increasing numbers of inmates with sentences of less than 1 year to be housed in prison.

Wisconsin - Operational capacity excludes contracted local jails, Federal, other State, and private facilities.

Counts include 886 offenders admitted as temporary probation and parole placements. 